MATEC Web of Conferences 37, 01003 (2015)

DOI: $10.1051 /$ matecconf $/ 20153701003$

(C) Owned by the authors, published by EDP Sciences, 2015

\title{
STATUS OF SOCIAL COMPETENCIES OF POWER ENGINEERS IN THE CONTEXT OF FORMING THE CONCEPT OF AN INTELLIGENT NETWORK OR SMART GRID
}

\author{
Ardashkin I.B. ${ }^{1, a}$, Korobeynikova L.A. ${ }^{2}$, Popova A.V. ${ }^{3}$ \\ 1 Institute of Humanities, Social Sciences, Technologies of National Research Tomsk Polytechnic University, \\ 634050, Tomsk, Russia \\ ${ }^{2}$ Institute of Arts and Culture of National Research Tomsk State University, 634050, Tomsk, Russia \\ 3 Institute of Humanities, Social Sciences, Technologies of National Research Tomsk Polytechnic University, \\ 634050, Tomsk, Russia
}

\begin{abstract}
The article reviews the trends which define development of power engineering in the world and in Russia. The authors emphasize that establishment of smart grids is the consequence of not only technological but also social transformations of a modern society. The authors sum up that social competencies are an integral part of professional skills of engineers who work in the field of power engineering. The authors make a hypothesis that the major (educational module) "Energy consultant for the population" might develop social competencies.
\end{abstract}

\section{Introduction}

Nowadays experts are talking about the establishment of a new concept of power engineering development in the world - the concept of intelligent electrical networks (Smart Grids). To be brief, this concept implies a more flexible operation of the electrical power system, this innovative technology allows for better power delivery, distribution, storage and management of the aforementioned systems. The essence of transformation of power supply system can be conditionally compared to transformation of communication using social networks when the organization of interaction (communication) is decentralized and this process appears to be spontaneous and depends on activity indicators of users of a particular network.

For power engineering, especially in Russia, this is a truly revolutionary step forward that should lead to fundamental changes not only in the power supply management system, but also in the training of engineers for this type of power engineering, as well as for consumers, including general population.

In this paper the authors will consider the aspect of engineering training of future specialists in the sphere of power engineering through the prism of defining the status of social competencies of the latter. According to the authors, social competences of power engineers become extremely important and it will be demonstrated in the paper.

\footnotetext{
a Corresponding author: ibardashkin@tpu.ru
} 
Firstly, it is important to point out what will happen in the system of power engineering operation to clarify the purpose and necessity to use social competences of an engineer including his professional sphere.

\section{Results and discussion}

We are living in an information society where creation, distribution and use of information are a significant activity. Information and communication technologies have resulted in an information explosion and are changing all aspects of social organization and human activity including economy, education and health. Power engineering is not an exception.

These technologies allow a person to get information quickly whereas a traditional method would be more time consuming. However, every opportunity implies a responsibility: we should understand what sort of information we are looking for. In other words, the information society provides opportunities but at the same time it increases the risks. It must be immediately clarified that a risk is a subjective choice of a person associated with his individual decision and awareness of responsibility for it.

The system Smart Grid presupposes changes in the development of power engineering that are similar in meaning. According to the representatives of Grenoble technical university Nouredine Hadjsaid and Jean-Claude Sabonnadiere "the current operation of electrical networks is based on four segments resulting from the structuring of the global electrical network" [1].

They are the following:

1. Most power is generated by large units installed in strategic location;

2. Transmission system that allows power to be transferred from large power plants to large consumption centers and other distribution systems. Management of the whole power system is highly centralized;

3. Distribution grids, those are the interface between the transmission grid and end use customer. They are characterized by unidirectional energy flows;

4. End users are mostly passive customers characterized by "non-controllable" loads and do not contribute to system management.

The system Smart Grid is primarily aimed at changing the $4^{\text {th }}$ segment and it can impact the operation of the first three segments. However, changing the essence of the $4^{\text {th }}$ segment is a key factor of the establishment of the model of intelligent electrical networks. According to French specialists "the first three segments, although institutionally unbundled in a deregulated environment with responsibility domains clearly defined, are closely interdependent and are governed by specific physical laws related in particular to generation-consumption balance or to the respect of technical constraints. The system as a whole was designed with the objective of generating, transmitting and distributing electrical energy under the best conditions of quality, security and economy" [1]. Moreover, the segment of end users has significantly changed.

The end users can, while being a consumer, become a producer of source of energy storage. The consumer, who was "passive" and did not dynamically interact with power system, is changing his behavior, particularly due to the design of smart meters, servers and power generators. The consumer thus becomes "active" or even "pro-active" when it includes all the possibilities of "load control", "local generation" or "energy storage" depending on regulations, market design or available technologies [1].

Thus, according to the aforementioned description, the $4^{\text {th }}$ segment of the power system is increasing the role of end users and it allows users to take a more active part in management of electric power supply. Nowadays end users do not play a giant role in electric power supply management. However, they have a limited number of instruments of influence to use and in the future they can play a significant role in contributing to the management of power supply. Reviewing scientific papers we can find analysis of opportunities that the end user might have in the system of power supply management. Particularly, D.Y. Apukhtin, A.E. Zhuravlev, A.S. Lifshitz point out the following opportunities for consumers: 
1. On-line control of hourly (and more frequent) parameters of meters.

2. Opportunity to control tariff diagrams to reduce electric power bills and save money by means of the use of simple electrical appliances during off peak periods when electricity prices are lower.

3. Opportunity to use "smart" appliances for automatic connection to power source during off peak periods.

4. Opportunity to connect private sources of power supply etc. [2].

According to the aforementioned authors, energy suppliers can also get important opportunities and this challenge make them compromise and share traditional authority. Particularly, energy suppliers can get the following benefits:

Firstly, to smoothen load diagrams (reduction of losses while generating and transmitting electric power).

Secondly, to attract the opportunity to use private sources of power supply to compensate peak load periods, reduce losses while transmitting electric power and to increase reliability of electrical power supply.

Thirdly, it will allow power supply companies to collect data of meters remotely and to pay the bills on time [2].

Getting important opportunities for consumers means also a certain level of responsibility $[3,4,5$, 6]. Therefore, it is obvious that power grids (power supply networks) become intelligent not so much due to the technical equipment, as due to a man and his willingness to organize his behavior accordingly (so that the society could only benefit from it). Smart grids require intelligent consciousness and behavior of not only consumers, but also of experts in the field of energy. According to the authors of the smart grid concept and the possibilities of its implementation in the Russian power industry, I.O. Volkov, V.R. Okorokov, R.V. Okorokov, B.B. Kobets, "energy system based on the concept of Smart Grid will provide great opportunities for entering the market for both consumers and producers by increasing the transfer capacity of bulk networks, making initiatives for collective management of consumption, location of distributed energy sources in the distribution networks, closer to consumers. At the same time, changing the status of the consumer as a participant in market relations conditioned by the ability of creation of their own sources of energy aimed at the development of a competitive environment in the electricity industry, encouraging the industry to change approaches and business models, that have been used for a long time, but proved to be ineffective in the modern conditions" [7].

In other words, smart grids are not just technological equipment, but also the relevant social organization which is crucial in the transition process to the formation of smart grids. The social organization, in its turn, involves the formation of relevant competencies allowing active participation in the Smart Grids. If the population does not possess such competences, hence, it does not actively manifests itself within the Smart Grid, so it results in the fact that such power system is not much different from the traditional model of power supply. It is not beneficial either to the energy sector, or to consumers.

For the situation to change, certain transformations are necessary both in the society itself (encouraging of the initiative, independence and creativity among population) and in relation to the specialists. The latter should possess not only professional, but also social competences in the Smart Grids system, that enable them to work with the population giving consultations on day-to-day issues and having bilateral contact. Unfortunately, the national system of bachelor training in the field of electrical power engineering and heat power engineering does not include the formation of such competences $[8,9]$.

The reference to the Federal State Education Standards of the third generation (FSES 3) on the educational program track 140400 "Power and Electrical Engineering" gives the following professional activities for future bachelors: design-and-engineering, engineering and manufacturing, organization and management, research and development, installation and setup, maintenance and service [10]. As it can be seen from this document there are no social and administrative or social and organizational types of professional activities in the list. 


\section{MATEC Web of Conferences}

It could be assumed that these competencies can be formed within organizational and administrative activity. But there are some specifications in FSES showing that it is not true. Organizational and administrative activities mean "

technical writing (schedules, instructions, plans, estimates, materials requisition, equipment), as well as the established reporting on approved forms; the execution of standardization work and preparation for certification of technical means, systems, processes, equipment and materials, etc." [10]. There are social competences in FSES: "GC 14 (general competency 14) - the ability and willingness to understand and analyze economic problems and social processes, to be an active participant of economic activity; GC 15 (general competency 15) - the ability to understand the nature and significance of information in the development of modern information society, to be aware of the dangers and threats that arise in this process, to follow the basic requirements of information security, including official secrets protection "[10]. However, the absence of the subject and the object of the professional activity in the FSES complicates the understanding of how, where, why these competencies can be applied.

The new educational standards on the educational program track 13.03.02 "Power and Electrical Engineering" (the so-called standard FSES 3+) does not contribute much into the issue. It has the differentiation of graduates' qualifications. As a result, they are supposed to get the qualification either of "an academic bachelor" or of "an applied bachelor", both of which have different types of professional activity. But they are very technology-oriented. So, the main professional activities for an academic bachelor are research, design, production and technology, organization and management, and for an applied bachelor they are manufacturing and technology, installation and commissioning, service, operation, organization and management.

Organization and management appears to be the common activity for both academic and applied Bachelor's programs on the educational program track 13.03.02 "Power and Electrical Engineering", but again this type of activity doesn't have social and managerial orientation. For an academic bachelor, it includes "staff work planning; work planning of primary production units; performance assessment; participation in decision-making" [11].

It can be concluded, that educational standards of the third and follow-on generations does not fully take into account the need for such competencies that are important for the formation of energy systems such as Smart Grid, since it is obvious that there are significant differences in the nature of the interaction of power supply specialists in the traditional model and in the Smart Grid model.

In one case, this relationship format is one-sided (it is passive for a consumer and over centralized for the representatives of producing and transmitting energy systems). And in another case, it is peer or at least a two-way relationship format, involving collaboration between a consumer and a producer, or a distributor, etc.

On the one hand, if this new format of relationship not to use for training specialists in the field of power systems, it is unlikely to be established and even more unlikely to contribute to the successful functioning of the Smart Grid. On the other hand, certain preparation work with the population is vital to make them aware of the new type of relationship with energy workers. Moreover, it is even inconsequent to expect any active and rational behavior on the part of the population if there is a lack of certain awareness.

It is difficult to imagine how social competences should be presented in the educational training of engineers in the field of energy. But it is no doubt, that this aspect plays an important role and has an indispensable nature. Perhaps there exists the need for specialization within the framework of the basic educational program on the principle of "energy consultant for the population". Maybe the additional educational module is required, which includes the development and evaluation of social and managerial competences of an engineer $[12,13]$.

In addition, it is important to implement the special policy at the national level for development and improvement of the population's energy literacy (literacy in energy consumption). Only the full set of measures and determination in the implementation of the necessary reforms can allow us to make great progress in the formation of Smart Grid. Apparently, it is unlikely to happen without the development of appropriate social competences. 


\section{Conclusion}

Thus, summing up, it should be stated that the formation of Smart Grid is not only technological, but also social in nature, that suggests that without the appropriate level of the preparation of the society such a transition is impossible. Consequently, the university system of training of engineers must take into account all professional aspects of a modern specialist and to identify not only the subject and activity structure of the education, but also the significant conditions of a specialist's professional activity, the absence of which makes this professional activity complicated.

The article is supported by the Russian Humanitarian Science Foundation grant 15-03-14049.

\section{References}

1. N. Khadzhsaid, J-C. Sabonnader. Smart Grids, Energetika budushchego, 60 (588), 77 (2009).

2. D. Yu. Apukhtin, A.E. Zhuravlev, A.S. Lifshits. Avtomatizatsiya i IT v Energetike, 4 (4), 4 (2013).

3. J.K. Gruber, F. Huerta, P. Matatagui, M. Prodanović. Appl. Energy, 160, 194 (2015).

4. S. Arndt, T. Sheveleva, C. Goeke. Energy, Sustainability and Society, 5, 1, 18 (2015).

5. P. Mesarić, S. Krajcar. Energy and Buildings, 108, 1 (2015).

6. M.B. Bulut, M. Odlare, P. Stiglson, F. Wallin, I.B. Vassileva, Energy and Buildings, 107, 254 (2015).

7. I.O. Volkova, V.R. Okorokov, R.V. Okorokov, B.B. Kobets. Contseptsiya intellektualnych energosistem I vozmozhnosti ee realizatsii v rossiiskoy elektroenergetike (Moscow, Institute narodnochozyastvenogo prognozirovaniya RAN, 2011) (in Russian).

8. M. Jarrah, M. Jaradat, Y. Jaraweh, M. Al-Ayyoub, A. Bousselham, Information Systems, 53, 190 (2015).

9. M.M. Eissa. Renewable Sustainable Energy Rev. 52, 1645 (2015).

10. Federalnyy gosudarstvennyy obrazovatelnyy standart vysshego professionalnogo obrazovaniya po napravleniyu podgotovki 140400 Elektroenergetika i elektrotechnika (Moscow, 2011) (in Russian).

11. Prikaz ob utverzhdenii federalnogo gosudarstvennogo obrazovatelnogo standarta vysshego obrazovaniya po napravleniyu podgotovki 13.03.02 Elektroenergetika i elektrotechnika. http://www.osu.ru/docs/fgos/vo/bak_13.03.02.pdf.

12. Y.A. Salchak, D.A. Sednev, K.V.Ǩrening, I.B. Ardashkin. IOP Conference Series: Materials Science and Engineering, 81, 1 (2015).

13. I.B. Ardashkin, A.N. Yakovlev, N.V. Martyushev. Adv. Mater. Res., 1040 (2014). 